\title{
The Positive Impact of Organizational Trust: a Systematic Review
}

\author{
Idha Rahayuningsih \\ Student of Psychology Doctoral Program, Universitas Airlangga, Surabaya \\ Faculty of Psychology, Universitas Muhammadiyah Gresik \\ idha.rahayuningsih@umg.ac.id
}

\begin{abstract}
The critical role of trust is to strengthen working relationships to ensure that organizations achieve their goals effectively. This study aims to explore the positive impact of organizational trust, namely trust towards colleagues, employers, and organization. We conducted a systematic review following the PRISMA guideline, highlighting the number of records that were identified, screened, assessed for eligibility, and included for the study. The literature search was conducted online by using the keyword "Organizational Trust" on three platforms, namely ScienceDirect, Sage, and ProQuest. We selected 30 research articles that use organizational trust as either a dependent, mediating or moderating variable. Next, we reviewed and assessed the papers according to their research objectives, role/function of the variable, authors, year of publication, number of subjects/research samples and findings. Findings show: (I) organizational trust can reduce turnover tendency, as well as increase the intention to stay at the organization, effectiveness of communication within the organization, change readiness, continuum improvement, innovative behavior, job satisfaction, organizational citizenship behavior (OCB), organizational commitment, safety motivation, and work performance; (2) As an independent variable, trust in coworkers could impact joint learning activities, willingness to share knowledge and ideas with coworkers, networking commitment, job satisfaction, and organizational commitment; (3) Trust in superiors reinforces organizational identification, work performance (the strongest level of positive correlation), job satisfaction, organizational citizenship behavior, organizational commitment as well as a predictor of burnout and depersonalization.
\end{abstract}

Keywords: Good impact, organizational trust, systematic literature review.

Received 8 September 2018/Accepted 24 February 2019 @JEHCP All rights reserved

\section{Introduction}

Business is done through relationships, and trust is the basis of productive relationships. People require a degree of trust towards their colleague to work together. For example, sometimes one needs to depend on others to do his or her respective tasks. This situation could be achieved by simply believing that we could trust the words that our colleagues have 
said. Mutually trusting relationships creates a sense of comfort. Trust inspires and produces energy (Reina \& Reina, 2008).

According to Covey and Merrill (2010), several characteristics of people with high organizational trust include: Sharing information openly, tolerating and encouraging learning from mistakes, fostering creativity and innovation; follower respect leaders; people speak in accordance with facts and express problems that are experienced openly; communicate and cooperate with fellow colleagues; easily give appreciation for the help/services of others; the meeting decisions are carried out effectively; prioritizing transparency in organizing; organization members act as they are; have accountability, feel positive energy and motivation

Costa (2017) explained that, after much debate, experts finally reached an agreement over the conceptand measurement of trust, including the core indicatorsof trust. Fulmer and Gelfand (2012) explained that some authors agree on the concept of trust as the basis of interrelated psychological conditions, including the willingness to accept vulnerabilities (conditions that are at risk) and positive expectations that the other party can be trusted.

Mayer et al., (1995) compiled theorganizational trust model. The model explains that three variables affect institutional trust: the characteristics of people who trust (trustor), the characteristics of people who are trusted (trustee) and perceived risk. The tendency for people to trust (the propensity of trustor) and the element of trust that people trust (trustee) affect the level of trust. The characteristics of people who trust are represented by the tendency of people to believe, ortrust some people more than others. Hofstede (1980) explained some of the cause of a person's tendency to trust, among others, differences in developmental experience, personality, and cultural background. The characteristics of people who are believed to be represented by three elements of trust include ability, good intentions, and integrity. Ability is the competence possessed by trusted people in a particular field. Good intention is the desire of people who are trusted to do good things to people who trust. Integrity is a person who is believed to have a set of critical values to guide behavior. 
Fulmer and Gelfand (2012) further explained, there were at least three trust targets (referents), namely interpersonal, team, and organization. Interpersonal references refer to other people such as a leader, negotiating partners, strangers, or coworkers. Interpersonal trust is directed at a specific person, which is distinguished from general trust that targets people in general.

The trust that one has that his or her colleague will fulfill their individual part of the work unit goals shows that one has trust in the work team. Trust in a work team increases the interdependence between team members (Koz Lowski \& Ilgen, 2006). Finally, trust in the institution. Ozyilmaz et al., (2017) defines organizational trust as the belief and positive expectation about the intention and behavior of various institutional constituents in managing the organization.

Klein, Dansereau, and Hall (Fulmer \& Gelfand, 20I2) explained that organizational trust operates at the individual, team, and organizational analysis. Although there are many findings from organizational trust research, there is no systematic review that studies the trust of cross-level organizations. No distinctions were made based on the antecedent variables nor consequences at each level. Thus, integrated research on organizational trust at cross levels is vital. For example, employees have different needs and concerns regarding their coworkers, leader or organization. Therefore, different antecedents and consequences can be different reference characteristics at each level of organizational trust. Based on the explanation above, our study aims to obtain empirical evidence from other studies that explored the positive impact of trust on colleagues, trust in supervisors, trust in the team and trust in the institution on behaviors of employees in the organization

\section{Method}

We conducted a systematic review of research papers that identifies the positive impact that organizational trust has over the behavior of employees within that organizations. Literature review was conducted following the PRISMA guideline, highlighting the number of records that were identified, screened, assessed for eligibility, and included for the study. 


\section{Stage I: Identification}

The research is carried out by conducting online searches of research results published in scientific journals, as well as the publication of dissertation reports, by entering the keyword "organizational trust" at https://www.sciencedirect.com,https://journals.sagepub.com, and https://search.proquest.com. There are no restrictions on the year of journal publication. After conducting an online search, there are 137 article titles by the topic of organizational trust.

\section{Stage 2: Screening}

At this stage, we exclude papers that studied about trust between organizations, trust between consumer and supplier as well as organizational online trust. Additionally, we also excluded records that only had abstracts.

\section{Stage 3: Eligibility}

Next, we selected quantitative research articles that examine the relationship of organizational trust variables with other variables. At this stage, 55 full papers were obtained from the previous 95 full papers. We excluded 40 articles, namely articles with the theme of developing trust ( trust development ), restoring organizational trust (repair trust), instrument development for organizational trust and articles with the literature review method.

\section{Stage 4: Included}

In the included stage, articles that meet two criteria are selected: articles studied using quantitative methods and those that place organizational trust as either an independent, moderating or mediating variable. At this stage, 30 titles placed organizational trust as either an independent, mediating or moderating variables. The number of organizations and countries where the research is conducted varies. The research was conducted in educational institutions, IT companies, manufacturing, retail, hospitals, and companies. The countries of origin of the study varied, among others, Indonesia, Turkey, China, Singapore, India, America, and Korea. 

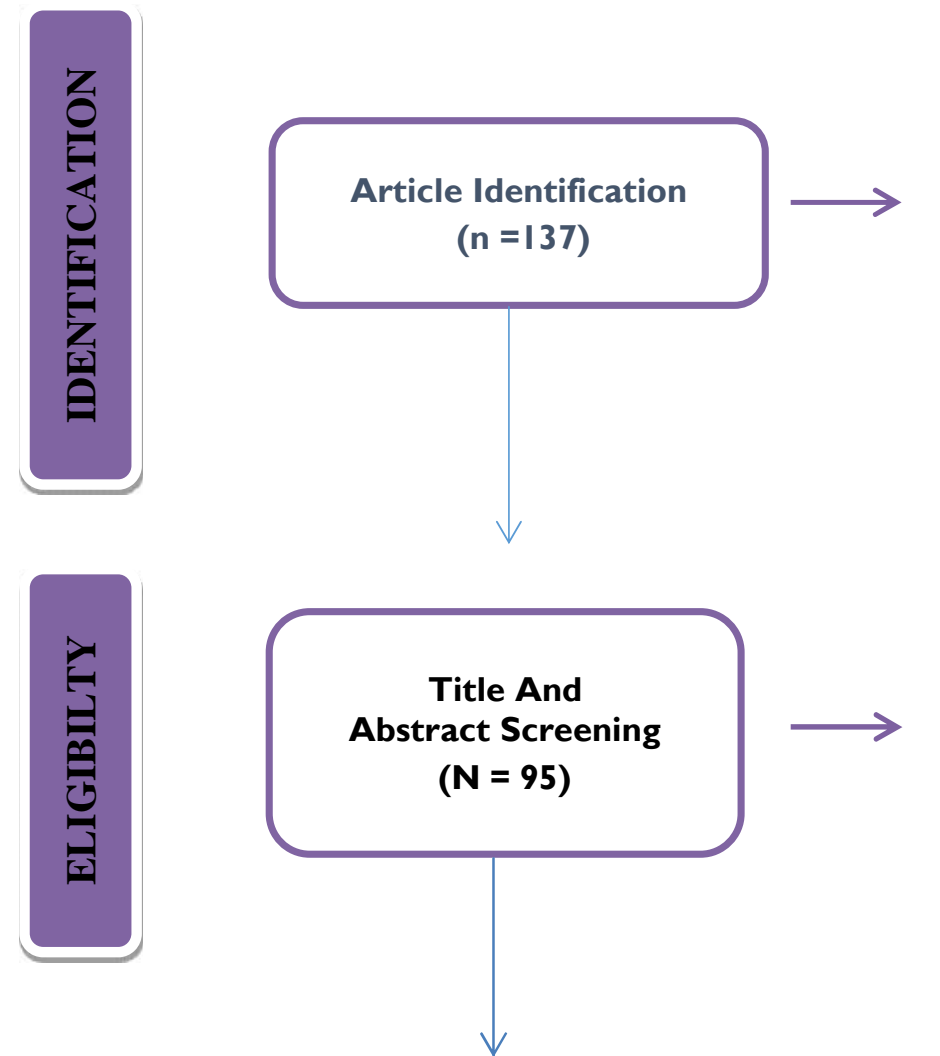

Article criteria :

- Same titles

- Only abstracts

- Trust between organizations

topic

- Trust between consuments and suppliers topic

- Organizational trust on line.
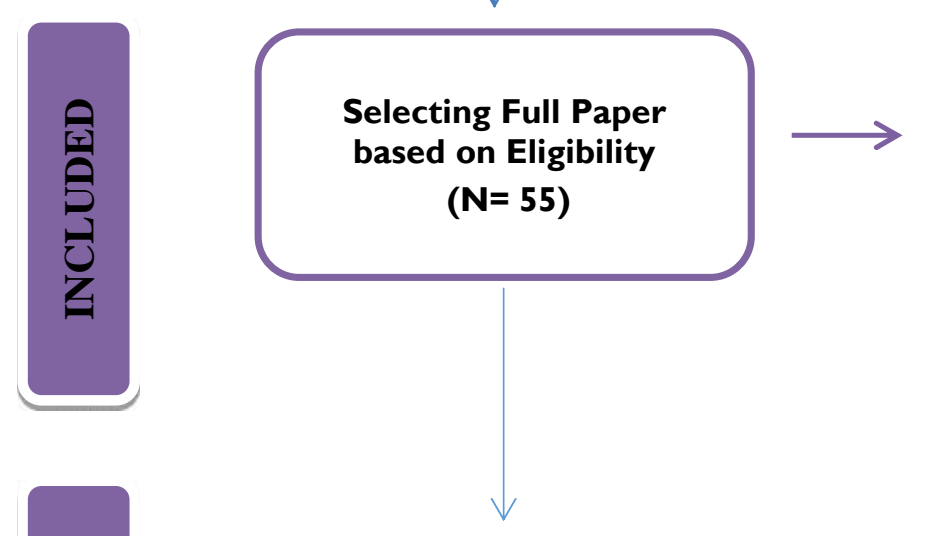

Article Shown :

- Development of organizational trust

- Improvement of organizational trust

- Development of organizational trust instrument
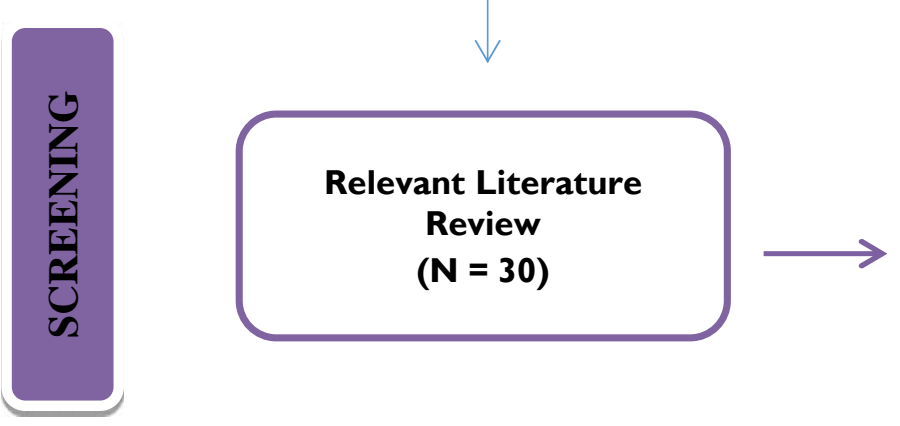

Selected articles :

Quantitative studies that placeorganizational trust as independent, mediator and moderator

Figure I. Literature Search with the PRISMA Method (Moher, Liberati, Tetzlaff, \& Altman, 2009). 


\section{Analysis}

Thirty articles were found to have used organizational trust as an independent, mediating or moderating variable in relation to the positive attitudes and behavior of employees. Thirty articles were reviewed and assessed based on the name of the author, year of publication, purpose of the study, role/function of the variable along with the measuring instrument, number of subjects/research samples and findings of the study. Table I depicts the source and number of articles obtained.

Table I

Source and Number of Relevant Articles

\begin{tabular}{|c|c|c|c|c|c|}
\hline No & $\begin{array}{l}\text { Journal Name } \\
\text { /Conference }\end{array}$ & $\begin{array}{l}\text { Number } \\
\text { of papers }\end{array}$ & NO. & Journal / Conference Name & $\begin{array}{l}\text { Number of } \\
\text { papers }\end{array}$ \\
\hline I. & $\begin{array}{l}\text { Journal of Leadership } \\
\text { \& Organizational } \\
\text { Studies }\end{array}$ & I & 14. & Front. The bus. Res. China & 1 \\
\hline 2. & Asia Pacific J Manage & I & 15. & $\begin{array}{l}\text { Journal of Hospitality \& } \\
\text { Tourism Research }\end{array}$ & I \\
\hline 3. & $\begin{array}{l}\text { Procedia-Social and } \\
\text { Behavioral Sciences }\end{array}$ & 3 & 16. & $\begin{array}{l}\text { Pacific Asia Journal of } \\
\text { Management }\end{array}$ & I \\
\hline 4. & $\begin{array}{l}\text { European Journal of } \\
\text { Work and } \\
\text { Organizational } \\
\text { Psychology }\end{array}$ & I & 17. & $\begin{array}{l}\text { Accident Analysis and } \\
\text { Prevention }\end{array}$ & I \\
\hline 5. & Leadership Quarterly & I & 18. & Journal of Business Ethics & I \\
\hline 6. & Management & I & 19. & $\begin{array}{l}\text { Industrial } \quad \text { Marketing } \\
\text { Management }\end{array}$ & $\mathrm{I}$ \\
\hline 7. & Sustainability & 1 & 20. & Global Business Review & I \\
\hline 8. & $\begin{array}{l}\text { Public Personnel } \\
\text { Management }\end{array}$ & I & 21. & $\begin{array}{l}\text { Management and Labor } \\
\text { Studies }\end{array}$ & 2 \\
\hline 9. & $\begin{array}{l}\text { Management and } \\
\text { Organization Review }\end{array}$ & 2 & 22. & $\begin{array}{l}\text { International Conference on } \\
\text { Business }\end{array}$ & I \\
\hline 10. & $\begin{array}{l}\text { Educational } \\
\text { Management } \\
\text { Administration \& } \\
\text { Leadership }\end{array}$ & I & 23. & Collegian & I \\
\hline II. & $\begin{array}{l}\text { Journal of Managerial } \\
\text { Psychology }\end{array}$ & 1 & 24. & Applied Nursing Research & 1 \\
\hline 12 & $\begin{array}{l}\text { SA Journal of ISSN } \\
\text { Human Resource } \\
\text { Management }\end{array}$ & 1 & 25. & $\begin{array}{l}\text { Journal of Occupational and } \\
\text { Organizational Psychology }\end{array}$ & 1 \\
\hline 13 & $\begin{array}{l}\text { Journal of the } \\
\text { American Society for } \\
\text { Information Science } \\
\text { and Technology }\end{array}$ & 1 & 26. & $\begin{array}{l}\text { UMI } 3557876 \quad \text { Published } \\
\text { ByProquest LLC }\end{array}$ & 1 \\
\hline
\end{tabular}




\section{Results and Discussion}

Our finding shows that organizational trust has several positive impacts towards employees in various aspects: organizational commitment,organizational citizenship behavior (OCB), job satisfaction, information seeking, continuous improvement, innovative behavior, physical and psychological health, effective communication, motivation for safety behavior, work engagement and task performance. Findings of research that support each positive attitude and behavior are presented below.

Job satisfaction

Discrepancy Theory (Locke) explains that job satisfaction is subjective. Satisfaction or dissatisfaction with some aspects of work reflects consideration of two values, namely differences in perceptions between desired and outcomes achieved, and the level of interest desired by individuals (Munandar, 200I). There are six research results that show correlation between organizational trust and job satisfaction (see Table 2).

Table 2

Study on Organizational Trust and Job Satisfaction

\begin{tabular}{llll}
\hline Authors & Type of Trust & Variable & Results \\
\hline Lee, \&Teo (2005) & Trust in co-workers & Independent & $\begin{array}{l}\text { Significant positive correlation between } \\
\text { organizational trust and job satisfaction. }\end{array}$ \\
\hline $\begin{array}{l}\text { Chathoth, et al. } \\
\text { (2007) }\end{array}$ & Trust in the institution & Independent & $\begin{array}{l}\text { Institutional trust has an impact on } \\
\text { service climate and job satisfaction. }\end{array}$ \\
\hline Kath, et al. (20l0) & Trust in the institution & Mediator & $\begin{array}{l}\text { Safety climate is positively related to } \\
\text { organizational trust, increased level of } \\
\text { organizational trust is a predictor of } \\
\text { increased job satisfaction. }\end{array}$ \\
\hline $\begin{array}{l}\text { Gilstrap, \& Collins, } \\
\text { (20I2) }\end{array}$ & Trust in supervisors & Mediator & $\begin{array}{l}\text { Trust in supervisors mediates the } \\
\text { impact of procedural, informational and } \\
\text { leadership justice transformational to } \\
\text { employee job satisfaction }\end{array}$ \\
\hline $\begin{array}{l}\text { Yadav, K, L. and } \\
\text { Gupta P. (20I7) }\end{array}$ & Trust in the institution & Mediator & $\begin{array}{l}\text { Organizational trust mediates the } \\
\text { positive correlation } \\
\text { procedural justice and job satisfaction }\end{array}$ \\
\hline $\begin{array}{l}\text { Ozyilmaz, A, et al. } \\
\text { (20I7) }\end{array}$ & Trust in the institution & Moderator & $\begin{array}{l}\text { Self-efficacy is positively correlated with } \\
\text { job satisfaction when the level of } \\
\text { organizational trust is high. }\end{array}$ \\
\hline
\end{tabular}

Findings of the study of Lee \& Teo (2005) conducted on 7I workers, findings of the study showed a significant positive relationship between organizational trust and job satisfaction. 
Chathoth et al. (2007) study on 77 starred hotel workers showed that organizational trust has an impact on service climate and job satisfaction. Kath et al. (2010) proved that safety climate is positively related to institutional trust. The increase in the level of institutional trust is a predictor of improvement in job satisfaction.

Yadav \& Gupta (2017) on 204 workers at The National Region of Delhi, discovered that organizational trust mediates a positive relationship between procedural justice and job satisfaction. Ozyilmaz et al., (2017) conducted a study on 300 workers in manufacturing companies in Turkey, among others, proving that self-efficacy was positively related to job satisfaction when there is high institutional trust. Gilstrap \& Collins (20/2) reported that, based on a study on 246 professional workers from large industrial companies in the Midwestern United States, trust in supervisors was found to mediate procedural, informational and transformational leadership justice towards employee job satisfaction.

The findings of these six studies indicate that the three types of organizational trust, namely trust in colleagues, supervisors and institution act as antecedents to organizational satisfaction. Research by Lee and Teo (2005) highlighted trust in coworkers as an independent variable toward job satisfaction. Trust in supervisors mediates procedural and informational justice and transformational leadership with satisfaction as proven by Gilstrap \& Collins (2012) while the research of Yadav and Gupta (2017) showed that organizational trust mediates the positive relationship between procedural justice and job satisfaction. Based on these two studies trust in the institution and trust in the supervisor acts as a mediating variable. Institutional trust acts as an independent, mediating, and moderating variable.

\section{Organizational Citizenship Behavior (OCB)}

Organizational Citizention Behavior (OCB) refers to the willingness of employees to carry out tasks beyond their primary duties and responsibilities. Organ (1988) described five OCB categories: a) Altruism: helping coworkers carry out their duties; b) Courtesy: respect others and prevent problems in interaction with coworkers; c) Sportsmanship: have a positive attitude and little to no complaining; d) Citizentionship: responsible for participating in organizational political life for organizational development; e) Conscientiousness: role far 
beyond the minimum required level. There are six research results about organizational trust and organizational citizenship behavior (OCB).

Table 3

Research on Organizational Trust and Organizational Citizenship Behaviors

\begin{tabular}{|c|c|c|c|}
\hline Authors & Type of Trust & Variable & Results \\
\hline Podsakoff (1990) & Trust in the boss & Mediator & $\begin{array}{l}\text { Transformational leadership affects } \\
\text { organizational citizenship behaviors } \\
\text { with trust to superiors as a } \\
\text { mediator. }\end{array}$ \\
\hline Liet al (20I I) & $\begin{array}{l}\text { Trust in the } \\
\text { institution }\end{array}$ & Mediator & $\begin{array}{l}\text { Organizational trust mediates the } \\
\text { relationship between } \\
\text { transformational leadership, } \\
\text { structural regulations and cultural } \\
\text { norms with organizational citizenship } \\
\text { behaviors and job performances. }\end{array}$ \\
\hline $\begin{array}{l}\text { Boru \& } \\
\text { slamoğlu, } \\
(2016)\end{array}$ & $\begin{array}{l}\text { Trust in the } \\
\text { institution }\end{array}$ & Mediator & $\begin{array}{l}\text { Organizational trust plays a role as a } \\
\text { mediator between power distance } \\
\text { and organizational citizenship behavior }\end{array}$ \\
\hline $\begin{array}{l}\text { Singh \& } \\
\text { Srivastava, } \\
(2016)\end{array}$ & $\begin{array}{l}\text { Trust in the } \\
\text { institution }\end{array}$ & Independent & $\begin{array}{l}\text { Organizational trust is a significant } \\
\text { predictor for organizational } \\
\text { citizenship behavior }\end{array}$ \\
\hline $\begin{array}{l}\text { Ozyilmaz et al., } \\
(20 \mid 7)\end{array}$ & $\begin{array}{l}\text { Trust in the } \\
\text { institution }\end{array}$ & Moderator & $\begin{array}{l}\text { Self-efficacy is positively correlated } \\
\text { to OCB when the level of } \\
\text { organizational trust is high. }\end{array}$ \\
\hline $\begin{array}{l}\text { Verburg et al., } \\
(20 \mid 8)\end{array}$ & $\begin{array}{l}\text { Trust in the } \\
\text { institution }\end{array}$ & Mediator & $\begin{array}{l}\text { Organizational trust mediates the } \\
\text { relationship between organizational } \\
\text { control (process, outcome and } \\
\text { normative) and organizational } \\
\text { citizenship behavior }\end{array}$ \\
\hline
\end{tabular}

Research on 303 respondents who held managerial positions at all levels in manufacturing and service sectors conducted by Singh and Srivastava (2016) showed that organizational trust is a significant predictor of OCB. The study also proved that organizational trust is a mediator in the relationship between perception of organizational support, justice procedure and communication with OCB. Verburget al. (2018) conducted a study on 105 workers and supervising couples in professional service companies in Singapore. Findings of the study indicated a correlation between organizational control (process, outcome and normative) and institutional trust of the employees, indicating a positive correlation between organizational trust and OCB. One of findings of the research by Ozyilmaz et al., (2017) on 
300 workers in manufacturing companies in Turkey, among others, prove that self-efficacy is positively related to $O C B$ when there is high organizational trust.

Boru \& slamoğlu (2016) examined 240 office workers from several companies in Turkey. Their findings showed that organizational trust acts as a variable that mediates between power distance and organizational citizenship behavior. In other words, when power distance increases the organization's trust decrease, resulting in OCB. Podsakoff, (1990) Research in 988 large petrochemical companies, one of findings showed that transformational leadership influenced organizational citizenship behaviors by mediating the trust of subordinates to their superiors. Li (20II) studied 444 workers from 82 companies in China and proved that organizational trust is a mediator between antecedent variables, including transformational leadership (Podsakoff, 1990). Singh\& Srivastava (2016) structural regulations and cultural norms with organizational citizenship behaviors and performance jobs.

Trust in supervisors acts as a mediating variable of the relationship between transformational leadership and OCB. Organizational trust acts as a mediating variable (Verburget al., 20I8), (Verburg et al., 2018) and (Boru \& slamoğlu, 2016). Ozyilmaz et al., (2017) portrayed organizational trust as a moderator.

\section{Commitment to Organizations}

Sheldon (I97I) defined organizational commitment as the employees' attitude towards the organization, indicated by the willingness to adjust personal identity with organizational identity. Buchanan (1974) broadened the concept of attitudes and views to include other dimensions, namely approving and supporting organizational goals and values; involving oneself in most organizational activities; showing loyalty by remaining to be a member of the organization. Four studies that linked organizational trust with organizational commitment. 
Table 4

Research on Organizational Trust and Organizational Commitment

\begin{tabular}{|c|c|c|c|}
\hline Authors & Type of Trust & Variable & Results \\
\hline $\begin{array}{l}\text { Zahra \& Mariatin, } \\
(20 \mid 2)\end{array}$ & $\begin{array}{l}\text { Trust in the } \\
\text { institution }\end{array}$ & Independent & $\begin{array}{l}\text { Organizational trust predicts an increased in } \\
\text { employee identification and engagement } \\
\text { against organizational commitments } \\
\text { (affective), perception of losses that will } \\
\text { appear if leaving workers (continuance). }\end{array}$ \\
\hline $\begin{array}{l}\text { Celep \& } \\
\text { Yilmazturk, (20I2) }\end{array}$ & $\begin{array}{l}\text { Trust in } \\
\text { organizations, } \\
\text { coworkers and } \\
\text { managers/superiors }\end{array}$ & Independent & $\begin{array}{l}\text { Organizational trust is a predictor significant } \\
\text { towards organizational commitment. } \\
\text { Trust in coworkers explains } 60 \% \text { of the } \\
\text { multi-dimensional variant of organizational } \\
\text { commitment. } \\
\text { Trust in the institution explains } 43 \% \text { of the } \\
\text { multi-dimensional variant of organizational } \\
\text { commitment. } \\
\text { Trust in managers explains I } 3 \% \text { of the multi- } \\
\text { dimensional variant of organizational } \\
\text { commitment. }\end{array}$ \\
\hline $\begin{array}{l}\text { Mukherjee \& } \\
\text { Bhattacharya, } \\
(2013)\end{array}$ & $\begin{array}{l}\text { Trust in the } \\
\text { institution }\end{array}$ & Mediator & $\begin{array}{l}\begin{array}{l}\text { Organizational trust } \\
\text { distributive } \\
\text { commitments. }\end{array} \\
\text { justice }\end{array}$ \\
\hline $\begin{array}{l}\text { Utamia et al. } \\
(20 \mid 4)\end{array}$ & Trust in Leaders & Mediator & $\begin{array}{l}\text { Trust in leaders mediates the relationship } \\
\text { between organizational political perception } \\
\text { and organizational commitment }\end{array}$ \\
\hline
\end{tabular}

Findings of the study by Zahra and Mariatin (2012) prove that the higher institutional trust is followed by an increase in employee identification and involvement with the organization (affective commitment component) and the perception of loss that will emerge from the worker (continuance commitment component). In line with a study that Celep and Yilmazturk (2012) conducted on 3/5 teachers from 18 elementary schools in Golcuk Kocaeli, organizational trust (in organizations, supervisors and colleagues) was found to be a significant predictor of organizational commitment.

One finding by Mukherjee \& Bhattacharya (2013) on 289 workers also showed that organizational trust is a mediator between distributive justice and affective commitment. One of the findingsfromUtamiaetal., (2014) based on a study of 103 employees in several companies in Jakarta and Bandung, proved that trust in leaders became the mediator between organizational, political perceptions and organizational commitment.

Trust in the institution acts as an independent variable in the study of Zahra \& Mariatin (20I2) and Celep \& Yilmazturk (20I2). Celep \& Yilmazturk (20I2) stated that trust in 
coworkers has the largest contribution $(60 \%)$ towards the multi-dimentional variant of organizational commitment. Confidence in the organization as a moderator as research Mukherjee \& Bhattacharya (20I3) and Utamia et al., (20I4) place trust in leaders as a mediator.

\section{Intention Turnover and Intention to Stay in Organizations}

Harnoto (2002) explained that turnover intention is the desire to leave the organization, with the need to find a better job as one of the primary causes. Three findings linked organizational trust with turnover intention. Meanwhile, a permanent intention of joining an organization refers to employees' intention to remain in the organization and maintain longterm working relationships (Johari, Yean, Adnan, Yahya, \& Ahmad, 2012). There are three results that linked organizational trust with permanent intention.

\section{Table 5}

Research on Organizational Trust, Turnover Intention, and Intention to Stay

\begin{tabular}{|c|c|c|c|}
\hline Authors & Type of Trust & Variable & Result \\
\hline $\begin{array}{l}\text { Kath et. al. } \\
(2010)\end{array}$ & $\begin{array}{l}\text { Trust in } \\
\text { Organizations }\end{array}$ & Mediator & $\begin{array}{l}\text { Safety climate has a positive relationship with } \\
\text { organizational trust. Increased level of } \\
\text { organizational trust predicts a decline in turnover } \\
\text { intention. }\end{array}$ \\
\hline $\begin{array}{l}\text { Vlachos et. al. } \\
(2010)\end{array}$ & $\begin{array}{l}\text { Trust in } \\
\text { Organizations }\end{array}$ & Mediator & $\begin{array}{l}\text { Organizational trust mediates the relationship } \\
\text { between the attribution of salespeople to } \\
\text { corporate social responsibility (CSR) and } \\
\text { outcomes that include loyal intention and } \\
\text { positive words delivered. }\end{array}$ \\
\hline $\begin{array}{l}\text { Boru \& } \\
\text { slamoğlu, } \\
(2016)\end{array}$ & $\begin{array}{l}\text { Trust in } \\
\text { Organizations }\end{array}$ & Independent & $\begin{array}{l}\text { Organizational trust impacts loyalty in } \\
\text { organizations with organizational self-esteem } \\
(\mathrm{SEBO}) \text { as a moderator. }\end{array}$ \\
\hline $\begin{array}{l}\text { Ozyilmaz et al. } \\
(2017)\end{array}$ & $\begin{array}{l}\text { Trust in } \\
\text { Organizations }\end{array}$ & Moderator & $\begin{array}{l}\text { Self-efficacy has a good impact on the turnover } \\
\text { intention when organizational trust is low }\end{array}$ \\
\hline $\begin{array}{l}\text { Cho \& Song, } \\
(20 \mid 7)\end{array}$ & $\begin{array}{l}\text { Trust in } \\
\text { Organizations }\end{array}$ & Mediator & $\begin{array}{l}\text { Organizational trust mediates between trust in } \\
\text { supervisor and autonomy support to reduce } \\
\text { turnover intention }\end{array}$ \\
\hline $\begin{array}{l}\text { Basit \& Duygulu, } \\
(20 \mid 8)\end{array}$ & $\begin{array}{l}\text { Trust in } \\
\text { Organizations }\end{array}$ & Independent & $\begin{array}{l}\text { Nurses with a high level of institutional trust } \\
\text { have the intention to continue working in the } \\
\text { hospital. }\end{array}$ \\
\hline
\end{tabular}

Basit \& Duygulu (2018) research on 265 hospital nurses in Turkey proved that nurses with a high level of institutional trust have the intention to continue working in the hospital. The role of organizational trust as a moderator can be seen in findings of a study on 300 workers 
in manufacturing companies in Turkey by Ozyilmaz et al., (20I7), which concluded that selfefficacy has a positive impact on turnover intention when organizational trust is low. Kath et al., (2010) showed that safety climate has a positive relationship with organizational trust. An increase in the level of organizational trust is a predictor of a decrease in the level of turnover intention. Findings of Vlachosetal., (2010) study on 63 sales revealed that organizational trust mediates the relationship between sales force attribution to Corporate Social Responsibility (CSR) and outcomes, including permanent intention and positive words delivered.

A study on 240 office workers from several companies in Turkey showed that institutional trust has an impact on loyalty to the organization, with organization-based self-esteem as a moderator (SEBO) (Boru \& slamoğlu, 2016). Cho \& Song (2017) also found that organizational trust mediates the relationship between trust in supervisor and autonomy support with turnover intention of 242 social workers in South Korea.

Kath et al., (2010), and Cho \& Song (2017) revealed that institutional trust acts as a mediating variable and is negatively correlated with turnover intention. On the contrary, Boru \& slamoğlu (2016) and Basit \& Duygulu (2018) showed confidence in the organization's role as an independent variable that is positively correlated with the intention to remain loyal to the organization. Vlachos et al., (2010) place organizational trust as a mediating variable between CSR attribution and intention to remain loyal. Meanwhile, Ozyilmaz et al., (2017) place institutional trust as a moderator variable, which self-efficacy has a good impact on the intention to leave when trust in organizations is low. The six results of the study are in line, showing the critical role that institutional trust has over the intention to remain or leave an organization.

Readiness to Change, Seeking Information, Continuous Improvement and Innovation Behavior There are six studies related to readiness to change, learning behavior, information seeking, continuous improvement and innovative behavior (see Table 6). Zayim and Kondakci (20I5) studied 603 teachers from 53 government schools in Turkey. Their finding revealed that organizational trust is a significant predictor of cognitive and emotional readiness and intention to change in a number of primary and secondary school teachers in Turkey. Yuet 
al., (2018) conducted a study on 935 workers from 63 companies in China whose results indicated that innovative behavior is predicted by worker-organizational relation with organizational trust as a mediating variable and innovative climate as a moderator. A study on 240 office workers from several companies in Turkey showed that trust in coworkers had an impact on the willingness to share knowledge and ideas with fellow colleagues with organizational self-esteem as a moderator (Boru \& slamoğlu, 2016).

Table 6

Research on Organizational Trust and Readiness to Change

\begin{tabular}{|c|c|c|c|}
\hline Authors & Type of Trust & Variable & Results \\
\hline Lee, (2004) & $\begin{array}{l}\text { Trust in } \\
\text { Organizational } \\
\text { Competence }\end{array}$ & Independent & $\begin{array}{l}\text { Organizational identification becomes a } \\
\text { moderator of the relationship between } \\
\text { trust in organizational competence and } \\
\text { business continuity improvement }\end{array}$ \\
\hline $\begin{array}{l}\text { Wong \& } \\
\text { Tjosvold, } \\
(2006)\end{array}$ & $\begin{array}{l}\text { Trust in co- } \\
\text { workers }\end{array}$ & Independent & $\begin{array}{l}\text { Trust among colleagues has a significant } \\
\text { positive correlation with learning } \\
\text { activities with colleagues (partner } \\
\text { learning). }\end{array}$ \\
\hline $\begin{array}{l}\text { Fang \& Kee } \\
\text { Wei, (2009) }\end{array}$ & $\begin{array}{l}\text { Trust in the } \\
\text { Community } \\
\text { Knowledge } \\
\text { Management } \\
\text { System }\end{array}$ & Independent & $\begin{array}{l}\text { Trust in the community knowledge } \\
\text { management system does not have a } \\
\text { direct impact on the intention of seeking } \\
\text { knowledge, the effect of trust occurs } \\
\text { indirectly through the mediation of } \\
\text { perceived community benefit. }\end{array}$ \\
\hline $\begin{array}{l}\text { Zayim \& } \\
\text { Kondakci, } \\
(2015)\end{array}$ & $\begin{array}{l}\text { Trust in the } \\
\text { institution }\end{array}$ & Independent & $\begin{array}{l}\text { Organizational trust becomes a significant } \\
\text { predictor of cognitive, emotional } \\
\text { readiness and changing intention }\end{array}$ \\
\hline $\begin{array}{l}\text { Boru \& } \\
\text { slamoğlu, } \\
(2016)\end{array}$ & $\begin{array}{l}\text { Trust in co- } \\
\text { workers }\end{array}$ & Independent & $\begin{array}{l}\text { Trust in coworkers has an impact on the } \\
\text { willingness to share knowledge and ideas } \\
\text { with fellow coworkers with a moderator } \\
\text { variable based on organizational self- } \\
\text { esteem (SEBO). }\end{array}$ \\
\hline $\begin{array}{l}\text { Yu et al. } \\
(20 \mid 8)\end{array}$ & $\begin{array}{l}\text { Trust in the } \\
\text { institution }\end{array}$ & Mediator & $\begin{array}{l}\text { Innovation behavior predicted by } \\
\text { variables of worker-organization } \\
\text { relationships with organizational trust as } \\
\text { intermediary variables and innovation } \\
\text { climate as moderators. }\end{array}$ \\
\hline
\end{tabular}

Wong \& Tjosvold (2006) proved that trust among colleague is positively and significantly correlated with learning activities with colleagues (partner learning). Fang \& Kee Wei (2009) examined 186 employees in the Knowledge Management System Community (KMS) which produced evidence that trust in the KMS did not have a direct influence on the intention to 
seek knowledge. The influence of trust occurred indirectly through the perception of community benefits. Trust has a stronger influence on perceptions of community benefits than perceived seeking effort. Findings of a study conducted on 490 shop workers in the Korean-US multi-national joint venture high-tech company by Lee (2004) showed that organizational identification is the moderator that links organizational trust and continuous improvement efforts.

Based on the six results of the study, it can be inferred that institutional trust is an independent variable for readiness to change (Zayim \& Kondakci, 20I5) and continuous improvement (Lee, 2004). Meanwhile, institutional trust acts as a mediator for innovative behavior (Yu etal., 2018). Trust in coworkers is an independent variable that relates to learning activities with coworkers (Wong \& Tjosvold, 2006) and the willingness to share knowledge and ideas with colleagues (Boru \& slamoğlu, 2016). Similarly, trust in KMS also acts as an independent variable from continuum seeking information, mediated by perceptions of KMS benefits (Fang \& Kee Wei, 2009). There are differences in consequences between trust in coworkers, in the community and organization.

\section{Physical and Psychological Health}

Two studies that show the relationship between organizational trust and physical and psychological health. First,Tănase et al., (201I) examined I 28 oil company workers, proving that assertiveness and institutional trusthas an impact on mental and physical health.

Second, Özgüra \& Tektaș (2018) study on 155 hospital nurses in Turkey revealed that there is a significant negative relationship between the level of organizational trust, consisting of trust in superiors, coworkers, and institutions, with burnouts in nurses. Maslach (2003) in Özgüra \& Tektaș (2018) defined burnout as syndromes that are stimulated by pressures from the organization as a result of the individual-organization interaction. Ozgüra \& Tektaș (2018) showed that, based on the findings of his study on 155 hospital nurses in Turkey, there is a significant negative relationship between organizational trust, consisting of trust in superiors, coworkers, and institutions, with burnouts in nurses. We found that the following factors are correlated with burnout: trust in superiors $(r=-0.304, p<0.01)$ and trust in institutions $(r=-0.335, p<0.01)$. Meanwhile, trust in coworkers is correlated with emotional 
fatigue $(r=-0.240, p<0.01)$ and depersonalization $(r=0.282, p<0.01)$. Trust in superiors have a negative correlation with depersonalization $(r=-0.315, p<0.0 I)$ and personal achievement $(r=-0.238, p<0.01)$. Both studies show that organizational trust directly plays a role in determining individual psychological health in the workplace.

Table 7

Research on Organizational Trust and Physical and Psychological Health

\begin{tabular}{|c|c|c|c|}
\hline Authors & Type of Trust & Variable & Results \\
\hline $\begin{array}{l}\text { Tănase et al., } \\
(20 \mathrm{I})\end{array}$ & $\begin{array}{l}\text { Organizational } \\
\text { Trust }\end{array}$ & Independent & $\begin{array}{l}\text { Assertive and organizational trust as } \\
\text { antecedent of psychological and } \\
\text { physical health. }\end{array}$ \\
\hline $\begin{array}{l}\text { Özgüra \& } \\
\text { Tektaș, } \\
(2018)\end{array}$ & $\begin{array}{l}\text { Trust to } \\
\text { employers, } \\
\text { coworkers, and } \\
\text { institutions }\end{array}$ & Independent & $\begin{array}{l}\text { A significant negative correlation } \\
\text { between organizational trust } \\
\text { consisting of trust to employees, } \\
\text { colleagues, and institutions with } \\
\text { burnout in nurses. }\end{array}$ \\
\hline
\end{tabular}

The Effectiveness of Organizational Internal Communication

Quach (20I3) used a sample of 5000 workers from business organizations, government, and educational institutions in his dissertation. His findings proved that institutional trust has a positive relationship with the effectiveness of internal communication in the workplace. Positive and strong levels of correlation for each sub-group identified through organizational environmental characteristics which include main business activities, face-to-face or virtual interactions, geographical area, type of organizational culture, and leadership style.

\section{Motivation, Work Engagement, Task Performance}

There are studies related to work engagement, two work-performance research, and one motivation study. Work engagement is defined as employees' positive attitude, behavior, and state-of-mind at work which leads to positive outcomes. This encompassed their physical, cognitive, and affective state. Other characteristics that describe employees with high work engagement include, find meaning in their work, feeling a sense of pride for being a part of the organization, works to achieve the overall vision and mission of the organization. Employees will work extra and strive for something to work above what is expected, both in 
time and energy (Schaufeli et al., 2006). Oosthuizen et al. (2018) studied 224 administrative workers in the retail and manufacturing industries in Africa. Findings of thestudy show that organizational justice has a positive relationship with institutional trust, while institutional trust has a positive relationship with work engagement. Work engagementacts as the mediating variable between organizational trust and cyberloafing. Lin (2009) conducted a study on $\mathbf{4 2 0}$ workers from 20 large North Taiwan industrial companies including traditional and high-tech companies. Thestudy proved that organizational trust mediates between corporate citizenship and work engagement.

Table 8

Research on Organizational Trust,Motivation, Work Engagement, and Work Performance

\begin{tabular}{|c|c|c|c|}
\hline Authors & Type of Trust & Variable & Results \\
\hline $\begin{array}{l}\text { Ning et al., } \\
(2007)\end{array}$ & $\begin{array}{l}\text { Trust in Direct } \\
\text { Bosses, } \\
\text { Colleagues and } \\
\text { Top Management }\end{array}$ & Independent & $\begin{array}{l}\text { Direct employee trust }(r=0.39) \text {, coworkers }(r= \\
0.28) \text { and peak management }(r=0.29) \text {. Each has } \\
\text { a positive correlation with employee } \\
\text { performance. }\end{array}$ \\
\hline Lin (2009) & $\begin{array}{l}\text { Organizational } \\
\text { Trust }\end{array}$ & Mediator & $\begin{array}{l}\text { Organizational trust mediates between corporate } \\
\text { citizenship and work engagement. }\end{array}$ \\
\hline $\begin{array}{l}\text { Kath et al., } \\
(2010)\end{array}$ & $\begin{array}{l}\text { Organizational } \\
\text { Trust }\end{array}$ & Mediator & $\begin{array}{l}\text { Organizational trust mediates the positive } \\
\text { relationship between safety climate and safety } \\
\text { motivation. }\end{array}$ \\
\hline Li et al., (20II) & $\begin{array}{l}\text { Organizational } \\
\text { Trust }\end{array}$ & Mediator & $\begin{array}{l}\text { Organizational trust mediates the relationship } \\
\text { between transformational leadership, structural } \\
\text { regulations and cultural norms with organizational } \\
\text { citizenship behaviors and job performances. }\end{array}$ \\
\hline $\begin{array}{l}\text { Verburg et al., } \\
(2018)\end{array}$ & $\begin{array}{l}\text { Organizational } \\
\text { Trust }\end{array}$ & Mediator & $\begin{array}{l}\text { There is a correlation between organizational } \\
\text { control (process, outcome and normative ) with } \\
\text { organizational trust, and shows the existence of } \\
\text { a positive correlation between organizational } \\
\text { trust and task performances. }\end{array}$ \\
\hline $\begin{array}{l}\text { Oosthuizenet } \\
\text { al. }(2018)\end{array}$ & $\begin{array}{l}\text { Trust } \\
\text { Organization }\end{array}$ & Mediator & $\begin{array}{l}\text { Justice organizations has a positive relationship } \\
\text { with organizational trust. Organizational trust } \\
\text { has a positive relationship with work } \\
\text { engagement. Work engagement mediates the } \\
\text { relationship between organizational trust and } \\
\text { cyberloafing. }\end{array}$ \\
\hline
\end{tabular}

On a study of 2500 workers in manufacturing companies, Ning etal. (2007) proved that employee trust in direct supervisor $(r=0.39)$, coworkers $(r=0.28)$ and top management $(r$ $=0,29)$ each has a positive correlation with employee performance. This shows that trust in direct superiors has the most robust relationship with employee performance. Her study proved that the influence of top manager trust in task performance is mediated by trust in 
direct supervisor. Verburg et al., (2018) examined 105 workers and supervisors at professional service companies in Singapore. Findings of the study indicate a correlation between organizational control (process, outcome and normative) and institutional trust, showing a positive correlation between organizational trust and task performance.

The study that Lietal., (201I) conducted on 444 workers from 82 companies in China proved that organizational trust is a mediator between the correlation between transformational leadership, structural regulations, and cultural norms has with organizational citizenship behaviors and job performance. Kath et al. (2010) showed that organizational trust acts as a mediator of the positive relationship between safety climate and safety motivation.

\section{Organization Identification}

Organizational identification is defined as the shared beliefs and attitudes among employees regarding the main, enduring, and different characteristics of the organization (Dutton \& Dukerich, 1991). Dutton, Dukerich \& Harquail (1994) asserted that identification is "the level of a member defining himself with the same attributes he believes is the defining organizational attributes. Employees with high identification with their organizations combine organizational goals as their own. As Ertürk \& Düzce (2010) have proven in a study of 518 blue-collar shipyard workers located in Istanbul and Kocaeli, Turkey, cognitive-based trust to supervisors strengthens the relationship between perceived competence, perceived control and organizational identification, while active-based trust to supervisors reinforce the relationship with goal internalization, perceived organizational support and organizational identification.

\section{Network Commitment}

Network commitment is defined as our belief that our partner/colleague also believe in the importance of being committed to maintain a long-term cooperative relationship (Morgan \& Hunt, 1994). Kurt e tal., (2016) proved that Kurt e tal., (2016) found organizational trust to be a mediator between spiritual experience and network commitment. 


\section{Conclusion}

Based on the findings of the literature review, we found several positive impacts of organizational trust. First, institutional trust can reduce turnover intention and increase the intention to stay in the organization. It also increases the effectiveness of communication within the organization, readiness to change, continuous improvement, innovative behavior, job satisfaction, $\mathrm{OCB}$, institutional commitment, safety motivation, and work performance. Second, trust in coworkers acts as an independent variable that correlates with joint learning activities, willingness to share knowledge and ideas with colleagues, commitment to networking, job satisfaction, and organizational commitment. Third, trust in superiors strengthen organizational identification, work performance (the strongest level of positive correlation), become a predictor of burnout, on the dimensions of depersonalization (the strongest level of negative correlation), job satisfaction, $\mathrm{OCB}$, institutional commitment.

\section{Limitations}

Several limitations need to be considered while reading this literature review. Firstly, the number of articles selected for each type/level of trust is not balanced, with the highest number of articles being abouttrust in the institution. Secondly, the level of analysis of the literature review is limited to mapping and describing the results; it has yet explained the reason for the differences in the consequences of each type of institutional trust. Lastly, our findings map the role of organizational trust as either an independent, moderating or mediating variable, but have not explained the reason for the role differences among several studies on the same consequent variables.

\section{Suggestions}

Future studies should explore the impact of organizational trust on the effectiveness of organizational communication, networking, and psychological health in the workplace in more depth. This is because the literature on those topics was found to be very limited. Additionally, literature needs to focus more on each level of organizational trust to determine the antecedent variables and their consequent variables. 


\section{References}

Fulmer, C. A., \& Gelfand, M. J., (20I2). At what level (and in whom) we trust: Trust across multiple organizational levels. Journal of Management, 38(4), I I67-I 230.

Börü, D., \& slamoğlu, G. (2016). Power distance, trust, organizational citizenship behavior. International Conference on Business, Economics, and Management, Yasar University, Izmir Turkey.

Basit, G. \& Duygulu, S. (20/8). Nurses' organizational trust and intention to continue working at hospitals inTurkey. Collegian, 25, 163-169.

Costa, A. C. (2017). Trust in organizations. Berrett-Koechler Publishers, Inc.San Francisco.

Covey, S. R., \& Merrill, R. R. (20I0). The speed of trust: A thing that is able to change everything. Tangerang: Karisma Publishing Group.

Celep, C., \& Yilmazturk, O. E. (20I2). The relationship among organizational trusts, multidimensional organizational commitment and perceived organizational support in educational organizations. Procedia - Social and Behavioral Sciences 46, 5763 - 5776.

Chathoth, P. K., Mak, B., \& Manactola, V. J. K. (2007). Employees' perceptions of organizational trust and service climate: a structural model of combining their effects on employee satisfaction. Journal of Hospitality \&Tourism Research, 3 I (3), 338-357.

Cho, Y. J., \& Song, H. J. (2017). Determinants of turnover intention of social workers: effects of emotional labor and organizational trust. Public Personnel Management, 46(I) 4I-65.

Düzce, A .E. (20I0). Exploring predictors of organizational identification: moderating role of trust on the associations between empowerment, organizational support, and identification. Work And Organizational Psychology, 19(4), 409-425.

Fang, Y. \& Kee Wei, K. (2009). The role of trust in promoting organizational knowledge seeking using knowledge management systems: An empirical investigation. Journal of the American Society for Information Science and Technology, 60 (3), 234-253.

Gilstrap, J. B., \& Collins, B. J. (20/2). The importance of being trustworthy: Trust as a mediator of relationship between leader behaviors and employees job satisfaction Journal of Leadership \& Organizational Studies, 19(2)I52-163.

Mayer, D. \& Schoorman, M. (1995). An integrative model of organizational trust. Academy of Management Review, 20(3), 709-734.

Özgüra, T. \& Tektaș, P. (2018). An examination of the correlation between nurses' organizational trust and burnout levels. Applied Nursing Research, 43, 93-97. 
Oosthuizen, A., Rabie. G. H., \& Beer, L. T. (20I8). Investigating cyberloafing, organizational justice, work engagement and organizational trust of South African retail and manufacturing employees. Journal of Human Resource Management: (Online) 207I-078X, (Print) I683-7584.

Ozyilmaz, A., Erdogan, B., \& Karaeminogullari, A.(20I8).Trust in organization as a moderator of the relationship between self-efficacy and workplace outcomes: A social cognitive theorybased examination. Journal of Occupational and Organizational Psychology, 91 (I), I8I-204.

Singh, U., \& Srivastava, K. B. L. (2016). Organizational trust and organizational citizenship behavior. Global Business Review, I 7(3) 594-609.

Kath, L.. M., Magley, V. M., \& Mamet, M. (2010).The role of organizational trust in safety climate's influence on organization outcome. Accident Analysis and Prevention 42, I4881497.

Kurt, Y., Yamin, M., Synovics, N., \& Sinkovics, R. (2016). Spirituality as an independent trust and network commitment: The case of Anatolian tigers. European Management Journal, 34, 686-700.

Lee, G., \& Teo, A. (2005). Organizational restructuring: Impact on trust and work satisfaction. Pacific Asia Journal of Management, 22, 23-39.

Li, P. P., Bai, Y., \& Xi, Y. (20II). The contextual antecedents of organizational trust: a multidimensional cross-level analysis. management and organization review. The International Association For Chinese Management Research.

Lee, H. J. (2004).The role of competence-based trust and organizational identification in continuous improvement. Journal of Managerial Psychology, 19(6), 623-639.

Mukherjee, K. \& Bhattacharya, R. (20/3). Exploring the mediating effect of organizational trust between organizational justice dimensions and affective commitment. Management And Labor Studies, 38(I \& 2) 63-79.

Ning, L., Yan Jin, Y., \& Mingxuan, J. (2007). How does the organizational trust work? The Bus. Res. China, I(4): 622-637.

Podsakoff, P. M., Moorman, R. H., \& Fetter, R. (1990). Leaders behaviors and their effects behavior and their effects on followers' trust in leader, satisfaction, and organizational citizenship behaviors. Leadership Quarterly, 7(2), I07-I42.

Paliszkiewicz, J.O. (20II). Trust management: Literature review. Management, 6(4): 3I5-33I.

Quach, H. (20I3). An analysis of organizational trust and communication effectiveness. IDI 3557876 Published By Proquest LLC (2013).Copyright In The Dissertation Held By The Author.

Reina, D. S, \& Reina, M. L. (2005). Trust \& betrayal in the work lace. Second Edition.PDF EBook, ISBN 978-I-57675-949-3. Berrett-Koehler Publisher, Inc.San Francisco. 
Tănase, S., Manea, C., M. Chraif, M., \& An ei, M. (20I I). Assertiveness and organizational trust as predictors of mental and physical health in a romanian oil company. ProcediaSocial and Behavioral Sciences 33, 1047-1051.

Utamia, A. F., Bangunb, Y. R., \& Lantuc, D. C. (20I4). Understanding the role of emotional intelligence and trust to relationship between organizational politics and organizational commitment. Procedia-Social and Behavioral Sciences II5, 378-386.

Verburg, R. M., Nienaber, A. N., Searle, R. H., Weibel, A., Den Hartog, D. N., \& Deborah E. Rupp, D. E., (2018).The role of organizational control systems in organizational trust and performance outcomes. Group \& Organization Management, 43(2) 179-206.

Vlachos, P. A., Theotokis, A., \& Panagopoulos, N. G. (2010). Sales force reaction to corporate social responsibility: attribution, outcomes, and the mediating role of organizational trust. Industrial Marketing Management, 39, 1207-1218.

Wong, A. \& Tjosvold, D. (2006). Collectivist values for learning in organizational relationships in china: the role of trust and vertical coordination. Asia Pacific Journal Management, 23, 299-317.

Yu, M.C., Mai, Q., Tsai, S. B., \& Yi Dai (20I8). An empirical study on organizational trust, employee-organization relationship and innovative behavior from the integrated perspective of social exchange and organizational sustainability. Sustainability 10, 207I1050.

Yadav, L. K., \& Gupta, P. (20I7). Procedural justice, satisfaction and organizational citizenship behavior: Mediating role of organizational trust-indian tourism industry study. Management and Labor Studies, 42(3) 275-292.

Zayim, M., \& Kondakci, Y. (20I5). An exploration of the relationship between readiness for change and organizational trust in turkish public schools. Educational Management Administration \& Leadership, 43(4) 610-625.

Zahra, Y., \& Mariatin, E. (20I2). The relationship between employee trust in organizations and commitments to organizations at PT.Bank X, Journal of Psychology, 7(2), 56-6I. 